\title{
Effectiveness on color and COD of textile wastewater removing by biological material obtained from Cassia fistula seed
}

\author{
Hiệu quả xủ lý màu và COD của nước thải dệt nhuộm bằng vật liệu sinh học \\ được chiết xuất tì̀ hạt Muồng Hoàng Yến
}

Research article

\begin{abstract}
Dao Minh Trung ${ }^{*}$, Le Hung Anh ${ }^{2}$, Nguyen Thi Khanh Tuyen ${ }^{1}$, Nguyen Vo Chau Ngan ${ }^{3}$
${ }^{1}$ Faculty of Resources and Environment, Thu Dau Mot University; ${ }^{2}$ Institute of Environmental Science, Engineering and Management, Industrial University of Ho Chi Minh City; ${ }^{3}$ Faculty of Resources and Environment, Can Tho University
\end{abstract}

\begin{abstract}
Nowadays, natural polymeric materials extracted from plants are the new alternatives for synthetic chemicals in water and wastewater treatment. The aim of this study is to evaluate the ability of Cassia fistula seed gum (CFG) as a coagulant aid with PAC in the treatment of textile wastewater. Jartest experiments were carried out to identify the optimal parameters of coagulation-flocculation for removing color and COD in synthesis wastewater containing Methyl blue and RB21 dyes, including $\mathrm{pH}$, settling time, PAC dose, the optimal CFG dosage in comparing with the cationic polymer. After that, actual textile wastewater was treated by using PAC, PAC plus cationic polymer, and PAC plus CFG for evaluating the role of CFG. CFG supplementation has assisted the process effects at nearly $98 \%$ color, $85 \%$ COD for RB21 and 90\% color, $70 \%$ COD for MB at the best dose of CFG $0.15 \mathrm{~mL}$ and $0.1 \mathrm{~mL}$, respectively. The optimized parameters for the coagulation of real textile wastewater using $\mathrm{PAC}$ were $\mathrm{pH}=6$ and dose $=0.6 \mathrm{~mL}$ can removal $66 \%$ of color. By adding CFG to PAC, the efficient of treatment was increased about $70 \%$ even at the lower dosage of PAC and CFG $(0.5 \mathrm{~mL}$ for each reagent). The yield of combining PAC and polymer was a little bit lower than PAC and CFG, for instant $68 \%$ color was decreased at the same condition. These achievements demonstrated a workable substitute of natural products such as Cassis fistula seed gum for synthetic chemical products in coagulation-flocculation process.
\end{abstract}

Hiện nay các loại vật liệu sinh hoc chiết xuất tì̀ thực vật đang được nghiên cứu ứng dụng trong xủ lý nuớc và nuoớc thải thay cho các chất hóa học. Mục tiêu của nghiên cứu này là đánh giá hiệu quả của việc sử dụng gum được chiết xuất tùu hạt cây Muồng Hoàng Yến (MHY) làm chất trợ keo tụ trong xủ lý nước thải dệt nhuộm. Thi nghiệm Jartest được tiến hành nhằm xác định các điều kiện tối ưu cho quá trình xủ lý nuớc thải tổng hợp chứa thuốc nhuộm Methyle Blue (MB) và RB21 bao gồm $p H$, thời gian lắng, liều PAC, liều gum MHY và liều polymer. Sau đó tiến hành xủ lý nước thải thật với các điều kiện thích hợp đã xác định nhằm đánh giá vai trò của gum MHY. Gum MHY làm tăng hiệu quả của quá trình xủ lý, đạt gần 98\% đối với độ màu, 85\% COD đối với RB21, 90\% độ màu và $70 \%$ COD đối với $M B$ với liều lương tương ưng là $0,15 \mathrm{~mL}$ và $0,1 \mathrm{~mL}$. Các thông số tối ưu cho quá trình xử lý trên mẫu nước thải thật là $p H=6$, liều $P A C=0.6 \mathrm{~mL}$ có thể làm giảm $66 \%$ độ màu. Bổ sung gum MHY làm chất trọ keo tụ giúp gia tăng hiệu quả xủ lý màu lên $70 \%$ dù vói liều lương rất thấp là $0,5 \mathrm{~mL}$. Hiệu suất xủ lý khi sủ dụng kết hợp PAC và polymer thấp hơn trong trưòng hợp sủ dụng PAC và gum $M H Y$, cu thể khoảng $68 \%$ độ màu được xử lý ở cùng một điều kiện. Những kết quả này cho thấy tiềm năng của việc sử dụng các vật liệu gum tự nhiên nhằm thay thế cho các hợp chất hóa học trong các quá trình keo tụ tạo bông để xủ lý nuớc thải.

Keywords: COD removal, textile wastewater, Cassia fistula seed gum, coagulation, flocculation 


\section{Introduction}

The wastewater generated by the textile industry has become the most pollution source among all industrial sectors due to the high volume discharge, complex chemical composition, and high concentration of pollutants (Verma et al., 2012). The textile processing often generates about $200-350 \mathrm{~m}^{3}$ of wastewater per ton of product. In Vietnam, textile wastewater has been reported as a high potential pollution source due to this industrial sector has developed rapidly, therefore increased the requirement of treating and controlling this wastewater. The main sources of wastewater generated by the textile wet-processing are the washing or scouring and bleaching of natural that response for $10 \%$ of dyes lost. Most of the wastewater produced by the textile industry is particularly associated with reactive azo dyes that are used for dyeing cellulose fibres. The effluent containing residual dyes, by-product, auxiliary chemical resulting in the high color and other pollutants (Hanif et al., 2007, 2008, Verma et al., 2012, Perng et al., 2015).

A number of methods applied in removing of color and COD of textile wastewater, including the combination of the chemical-physical treatment with a biological step, as well as some new emerging techniques like sonochemical or advanced oxidation. By comparing to other technologies, coagulation flocculation is an effective method because of the economically feasible and high color removal capacity (Bratby, 2007, Verma et al., 2012). The most applicable technology is coagulation flocclulation by chemical agents (PAC, Ferrous sulphate, Alum, Magnesium chloride) with the aid of chemical polymer in both laboratory research and in actual treatment (Perng et al., 2014, 2015).

Chemical coagulation and flocculation involves the addition of materials to stabilize the suspended particles (change the physical state of dissolved and suspended solids), allowing particle collision and growth of floc then removal them by sedimentation. In water treatment, coagulation is used as pretreatment for removal of suspended or colloidal materials that do not settle out on standing or may settle by taking a very long time coagulation (Metcalf \& Eddy, 2007, Verma et al, 2012,). However, the major limitation of this process is the generation of sludge and ineffective decolourisation of some soluble dyes.

To improve the efficiency of coagulation process, a number of high molecular weight compounds such as synthetic polymers or natural origin may be recommended. These polymers can function as coagulant itself or in the form of coagulant aids/bioflocculants, depending upon the wastewater and polymer characteristics (Metcalf \& Eddy (2007).

Nevertheless, chemical coagulants generally involve in less biodegradability and toxicity. For example, acrylamide is very much toxic and gives severe neurotoxic effects (Bratby, 2007). Toxicity effect due to cationic polymers to the plants has been established long back (Gao et al., 2001, 2007). The major advantage of natural polymer is its non-toxicity to the environment and biodeg- radability. Therefore, the effluent after natural polymer treatment can be treated by biological means and will not pose any harm to the biological organisms. The sludge generated by the natural polymers can further be treated biologically or can be disposed of safely as soil conditioners because of their non-toxicity (Yin, 2010, Subramonian, 2014). Hence, there is an urgent need to establish the use of natural low-cost polymers for textile wastewater treatment.

Natural polymeric materials extracted from plants are the new alternatives for synthetic polymers in water and wastewater treatment as they enhance the treatment's efficiency besides of prominent characteristics, such as highly biodegradable, non-toxic, non-corrosive, less sludge voluminous and $\mathrm{pH}$ independent. Nowadays, natural coagulants such as Guar gum, seed extract gum from Strychnos potato rum, Moringa Olifeira, and Cassia fistula, and others extraction from an animal (Chitosan) or micro-organism (Xanthan gum) have been used as a flocculation aid with the chemical coagulants. Cassia obtusifolia seed gum has the potential to treat $87 \%$ TSS and $55 \%$ COD comparable to those obtained in treatments using alum. In addition, the most prominent operating factors in the coagulation-flocculation process using the natural coagulant were the seed gum dosage, initial $\mathrm{pH}$ of wastewater and settling time (Damayanti, 2011, Shak \& Wu, 2014, 2015; Choy et al., 2014).

Cassia fistula is recently planted in many areas in Vietnam since it has the beautiful flowers. Cassia fistula is commonly known as Amaltas in Pakistan, as Indian Labrum in India, as Canafistula in Brazil and as Golden Shower. It belongs to family Fabaceae, genus Cassia, species Fistula. Cassia fistula presents a high content of ionizable groups such as carboxyl, carbonyl, alcoholic and amino groups (Hanif et al. ,2007, 2008, Shak et al., 2015). Research of Mazhar Abbas (2007) examined the effect of various pretreatments on the capacities of Cassia fistula biomasses to remove $\mathrm{Cr}$ (III) and $\mathrm{Cr}$ (VI) and to study the effect of different conditions such $\mathrm{pH}$, initial metal concentration, dosage, particle size and time require for the establishment of equilibrium. CFG was used in combination with PAC for decolorization of reactive dyeing wastewater and shown the decolorization efficiencies of both dyes reached over high values at $40 \%$ volume fraction of gum A study in which Cassia fistula gum was used as an aid with PAC achieved the decolorization efficiencies of dyes containing reactive dyes Blue 19 (RB19) and Black 5 (RB5) reached over 92.6\% (RB19) and $94.2 \%(\mathrm{RB} 5)$ at $40 \%$ volume fraction of gum (Perng and Bui, 2014, 1015).

The performance of the coagulation_flocculation process has affected by selection of coagulant, flocculant aids, optimization of process parameters such as $\mathrm{pH}$, the dosage of coagulant/flocculant aids, mixing time, and settling time (Hanif et al., 2007 Mazhar Abbas, 2007; Shak, 2014; Perng, 2014). A coagulation_flocculation system for textile wastewater treating should be designed based on the achieved optimum conditions.

This article is an attempt to evaluate the effectiveness of Cassia fistula seed gum as the coagulant aid with chemi- 
cal coagulant for textile's wastewater treatment in the batch mode.

\section{Materials and Methods}

\subsection{Materials}

- The main coagulant used in this study is PAC (Polyaluminum chloride) has the density of $0.3 \mathrm{~g} / \mathrm{cm}^{3}$ and containing $30 \% \mathrm{Al}_{2} \mathrm{O}_{3}$.

- Cassia fistula seed gum (CFG) was produced via the process that illustrated in figure 1 . The seeds of the Cassia fistula tree were collected in Thu Dau Mot city, Binh Duong province, Vietnam when they became ripe and were dried under the sun. The dried seeds then were ground into powder in a blender before the extraction step. The polysaccharide from CF seed was extracted by Soxhlet system with quantity ratio $1: 1$ of n-hexane solution: powder for 24 hours. The fibrous mass was made by ethanol precipitation for 48 hours and then was dissolved in distilled water and precipitated again to purify the gum. In the last step, the gum was dried at $50^{\circ} \mathrm{C}$ for 2 hours to obtain the complete CFG.

- The anionic polymer was used to assist the flocculation of the colloids after coagulation.

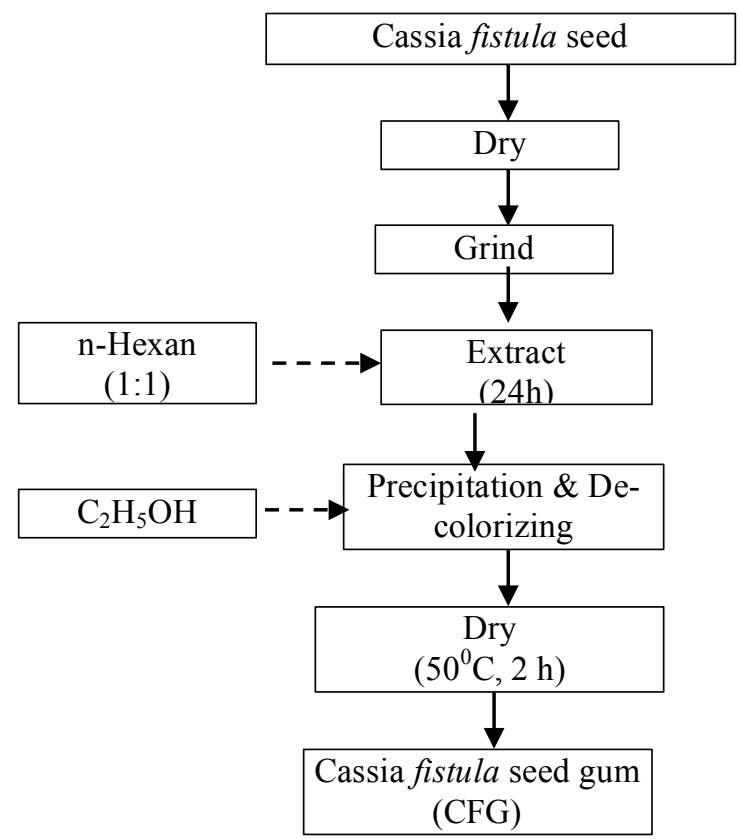

Figure 1. Cassia fistula seed gum producing process.
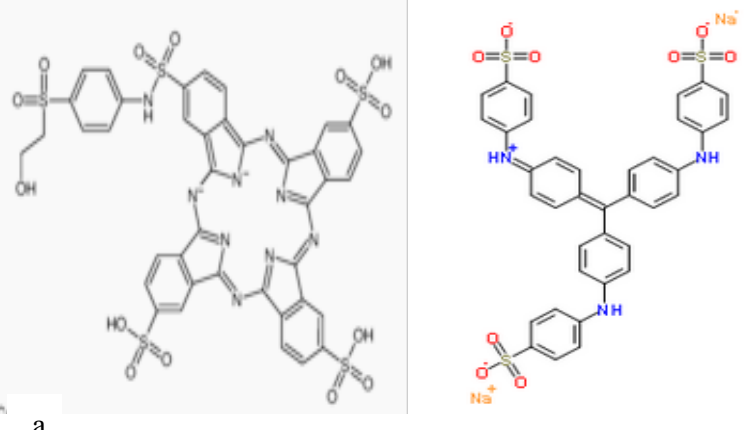

Figure 2. Chemical structure of RB21 (a) and MB (b)
- The synthetic wastewater was prepared by adding two familiar dyes in textile industry including RB21 - Reactive Blue 21 and Methyl Blue to determine the optimal conditions for the coagulation_flocculation process. The chemical structure of these materials as shown in figure 2 .

- The actual textile wastewater was obtained at the Phuoc Long wastewater treatment plant for studying the effect of PAC coagulant in the aid of polymer and CFG.

\subsection{Methods}

In order to evaluate the feasibility of CFG as a coagulant with PAC for the treatment of textile wastewater at the pilot scale, it is necessary to conduct the batch experiments to determine the optimal conditions. Figure 3 illustrated the methodology of this study.

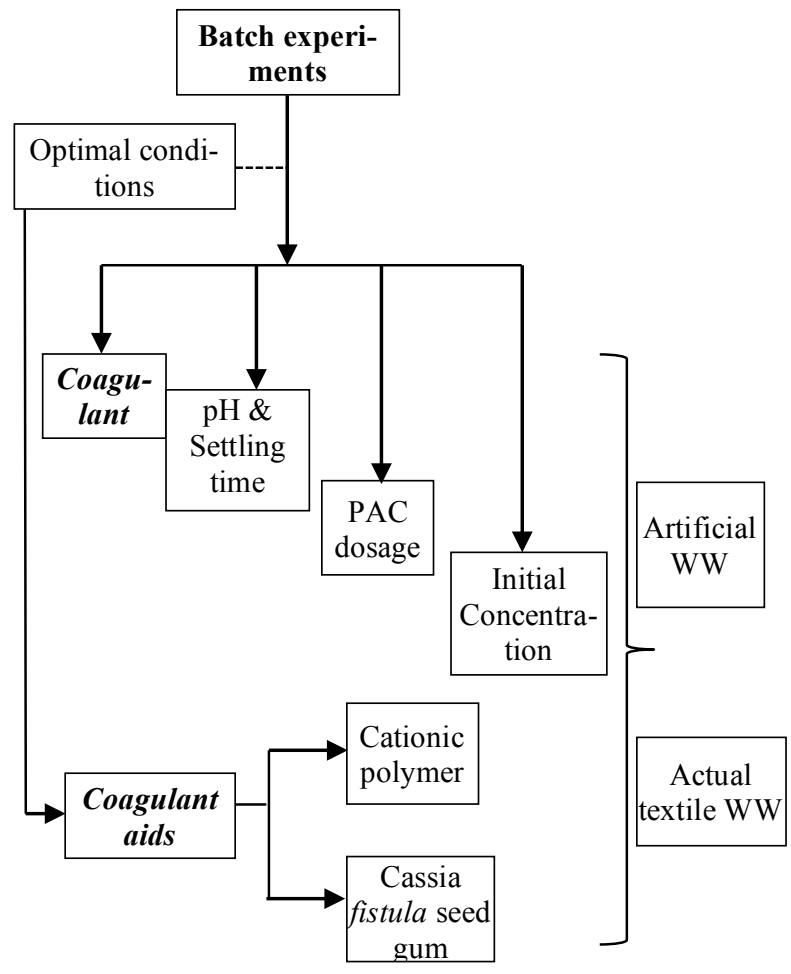

Figure 3. The studying scheme

\subsubsection{Batch reactor set up}

A Lovibond Jar-test was utilized in batch experiments to determine the optimal conditions of the coagulation_flocculation process with the artificial wastewater, including:

- The sample containing: 6 places for 6 beakers $0.5 \mathrm{~L}$.

- The mixing vane: 6 impellers that can control the mixing rate and reaction time.

The optimal value of each parameter was examined by experiments in which target parameter fluctuated and the others were controlled; the highest of color removing efficiency indicated for the optimal condition as shown in table 1 and figure 4.

For evaluation of treatment's effectiveness (H\%), the following equation was applied: 


$$
H=\frac{C_{0}-C_{a}}{C_{0}} \times 100, \%
$$

Where:

$\mathrm{C}_{0}$ : The initial concentration of COD $(\mathrm{mg} / \mathrm{L})$ or the color (Pt-Co);

$\mathrm{C}_{\mathrm{a}}$ : The concentration of COD $(\mathrm{mg} / \mathrm{L})$ or the color $(\mathrm{Pt}-\mathrm{Co})$ after treatment.

The $\mathrm{pH}$ and sedimentation time were observed by experiments at these conditions: $\mathrm{pH}$ was changed in the range from 3 to 12 by adding $\mathrm{HCl} 1 \mathrm{M}$ and $\mathrm{NaOH} 0.1 \mathrm{M}$, the fast stirring rate was $200 \mathrm{rpm}$ for 1 minute and the slow stirring rate was $45 \mathrm{rpm}$ for 15 minutes, the sedimentation time was 15,30 , and 45 minutes.

The optimal dosage for PAC in treatment of RB21 and MB was examined at these conditions: the volume of PAC was $0.1,0.15,0.2,0.25,0.3,0.35 \mathrm{ml}$; the $\mathrm{pH}$, sedimentation time obtained from previous experiments; the fast stirring rate was $200 \mathrm{rpm}$ for 1 minute and the slow stirring rate was $45 \mathrm{rpm}$ for 15 minutes.

Table 1. Detail of optimal conditions determination

\begin{tabular}{|c|c|}
\hline Parameters & Value \\
\hline $\mathrm{pH}$ & $3 ; 4 ; 5 ; 6 ; 7 ; 8 ; 9 ; 10 ; 11$ \\
\hline $\begin{array}{l}\text { Concentration of dye, } \\
\mathrm{mg} / \mathrm{L}\end{array}$ & $150 ; 200 ; 250 ; 300$ \\
\hline \multicolumn{2}{|c|}{ The dosage of coagulant and coagulant aids, mg/L } \\
\hline $\mathrm{PAC}, \mathrm{ml}$ & $0.1 ; 0.15 ; 0.2 ; 0.25 ; 0.3 ; 0.35$ \\
\hline Polymer $(0,05 \%), \mathrm{ml}$ & $0.05 ; 0.1 ; 0.15 ; 0.2 ; 0.25 ; 0.3$ \\
\hline CFG $(0,05 \%), \mathrm{ml}$ & $0.05 ; 0.1 ; 0.15 ; 0.2 ; 0.25 ; 0.3$ \\
\hline Reaction time, minute & $15 ; 30 ; 45 ; 60$ \\
\hline Input sample & $\begin{array}{c}\text { Analyzing the initial } \\
\text { COD, color }\end{array}$ \\
\hline $\begin{array}{l}\text { Adjustment the experi- } \\
\text { ment parameter }\end{array}$ & \\
\hline $\begin{array}{c}\text { Mixing, flocculation, } \\
\text { sedimentation }\end{array}$ & \\
\hline Out put & Analyzing COD, color \\
\hline
\end{tabular}

Figure 4. The batch experiment for determination optimal condition.

The best combination of cationic polymer and PAC then determined with the previous optimal parameters and volume of polymer adding was $0.05,0.1,0.15,0.2,0.25$, 0.3 respectively. The best dosage for utilizing CFG was detected by color and COD removing at the volume of CFG $0.05,0.1,0.15,0.2,0.25,0.3 \mathrm{~mL}$ and other optimal parameters.

After carried out batch experiments with artificial wastewater containing RB21 and MB, actual textile wastewater were treated for evaluating the real ability in COD and color removing under the optimal conditions. Parameters were evaluated included: $\mathrm{pH}$, PAC dosage, CFG aid dosage, and cationic polymer aid dosage.

\subsubsection{Analyzing methods}

Samples were analyzed for such parameters as $\mathrm{pH}, \mathrm{COD}$, and color; following the standard methods. UV-VIS spectrophotometry was used to determine the absorb capacity in COD analyzing. The color of the sample was detected according to Platinum-Cobalt color standard test method for liquid (APHA, 1999).

\section{Results}

\subsection{Effect of $\mathrm{pH}$ and sedimentation time}

It has been improved in various research that $\mathrm{pH}$ plays an important role in the coagulation flocculation process because it not only affects on the characteristic of reagents but also influents the hydrolysis and solubility of dye. The result of color removal by PCA depending on $\mathrm{pH}$ has shown in figure 6. The efficiency in color treatment has changed as the $\mathrm{pH}$ changed and the optimal of $\mathrm{pH}$ was different due to the kind of dye. Besides, the time of sedimentation has a significant effect on the final outcomes. In particularly, at $\mathrm{pH}=4$, and sedimentation time $=30$ minutes, the color removing yield reached to $93 \%$. In the case of Methyl Blue, $\mathrm{pH}=6$ has the most impact, with the settling time of 30 minutes, almost $50 \%$ of $\mathrm{MB}$ was reduced. It could be seen that at lower $\mathrm{pH}$ the efficiency was higher that was similar to the finding of $\mathrm{Mu}-$ hammad Asif Hanif (2008). In the real performance of colored wastewater, the hydrolysis of dye has fluctuated by the $\mathrm{pH}$. At the alkaline $\mathrm{pH}$, its hydrolysis is faster than the coagulation process, so that dye can not bind to the PAC. At acidic and neutral $\mathrm{pH}$, the hydrolysis becomes slower and improves the combination of dye material and PAC (Perng, Yuan- Shing, 2014).

It was reported by Peavy et al. that $\mathrm{pH}$ influenced to the coagulation at different ranges varying by the dye and coagulant characteristics. If $\mathrm{pH}$ is below the isoelectric point of metal hydroxide while precipitation enhanced by a suitable polymer, the positively charged polymers will prevail and predominate the negatively charged colloids by charge neutralization. Above the isoelectric point, anionic polymers will predominate so that particle is adsorbed and develop the bridge. At high dose of metal ion coagulants, a sufficient degree of oversaturation occurs to produce a rapid precipitation of a large quantity of metal hydroxide, catching the colloidal particles to build floc (Peavy et al., 1985). 


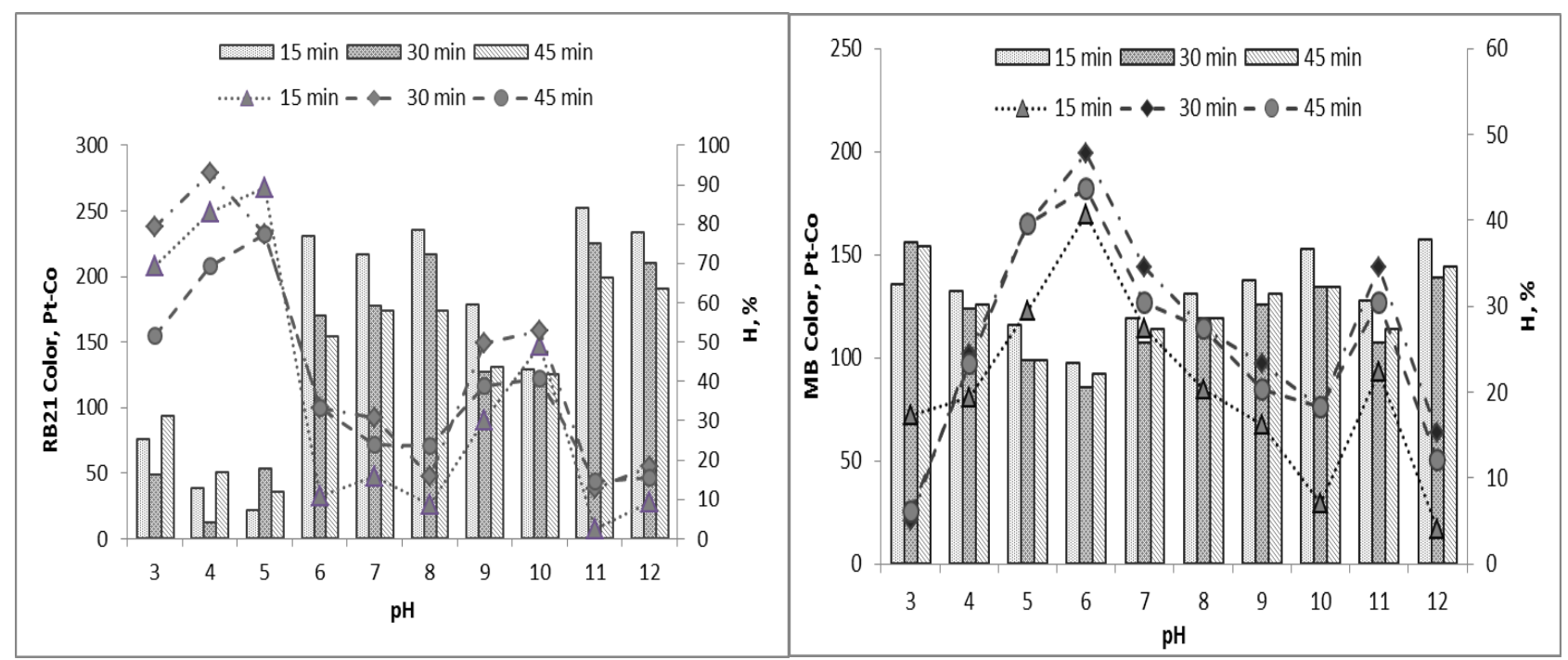

Figure 6. The effluent's color and efficiency of removing of RB21 (a) and MB (b).

\subsection{Effect of PAC dosage}

Coagulant dose has considered a most important indicator for coagulation_flocculation. As pointed in figure 7, the increasing of PAC dose from $0.1 \mathrm{~mL}$ to $0.2 \mathrm{~mL}$ has enhanced the proportion of color and COD treatment. Adding PAC to the system more than $0.2 \mathrm{~mL}$ has restricted the process. At lower concentration of PAC, the positive charges are not sufficient to destabilize the dye particles than that at higher PAC dosage. The effectiveness in the treatment of COD and color increased by the supplementation of coagulant but at overdosage value, the PAC potential will be lowered. This phenomenon was explained by the fact that the colloid would be re-stabilized at high concentration of coagulant (Metcalf \& Eddy, 1991; Le Hoang Viet, Nguyen Vo Chau Ngan, 2014).

At optimal conditions of $\mathrm{pH}$ and PAC dosage, the removing percentage of color was around $90 \%$ for RB21 and nearly $60 \%$ for MB. A similar result was found by Perng, Yuan- Shing and Manh Ha Bui (2014) when they used $\mathrm{PAC}$ to treat the colored dyeing wastewater.

\subsection{The efficiency of cationic polymer}

Furthermore, PAC at low concentration would diminish the coagulation even at optimal $\mathrm{pH}$ due to the fact that there was not enough positive charge to make the colloid unstable before they can aggregate into a larger particle. The auxiliary coagulant has used for enhancing the flocculation of suspended particular is wastewater (figure 8). In the assistance of cationic polymer at 0.1 for $\mathrm{MB}$ and 0.2 for RB21, the COD removing's efficiency was increased to $96 \%$ and $80 \%$, respectively. The color after treatment was also reduced significantly at those conditions. The other studies have indicated that the cationic polymer has a strong effect to the wastewater that has contained a high value of organic matter. In these reactions, cationic polymer has a high ability to attract the suspended solid and neutralize their surface charge so that it helps to reduce the PAC using, produce a small volume of more concentrated and rapid settled floc.

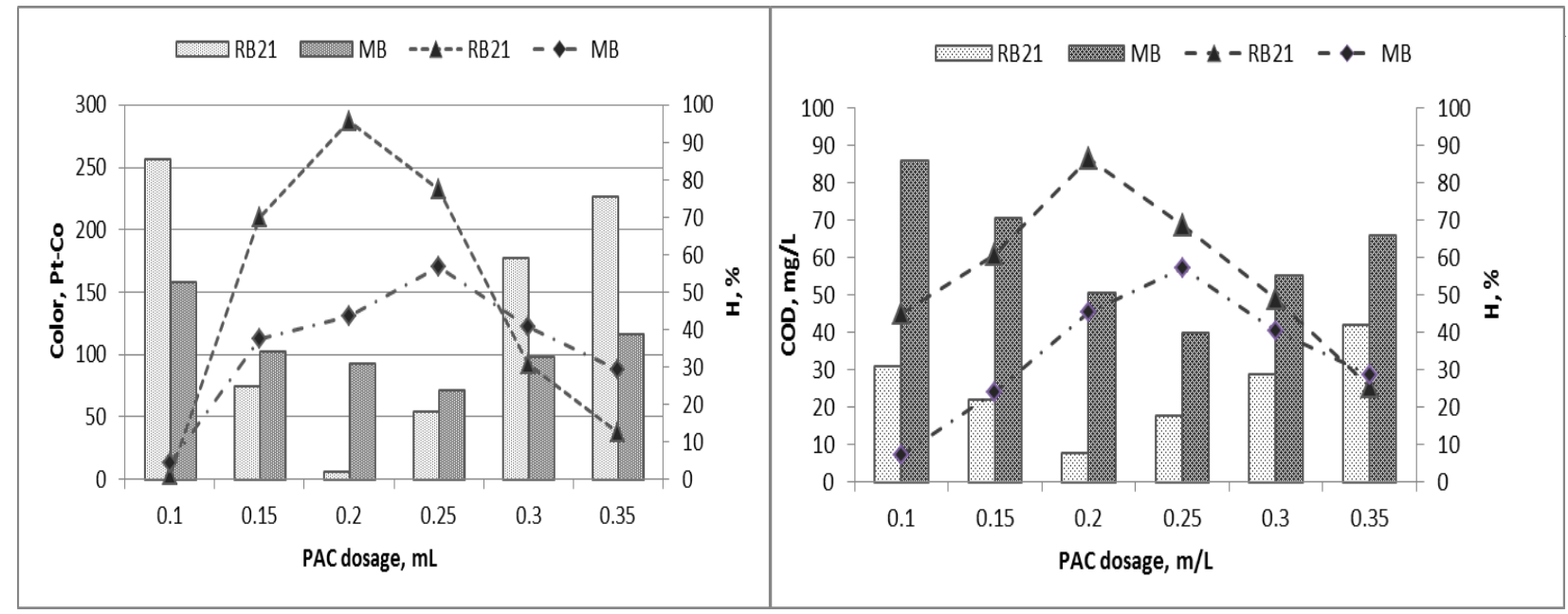

Figure 7. The efficiency of removing color (a) and COD (b) at different PAC dose. 


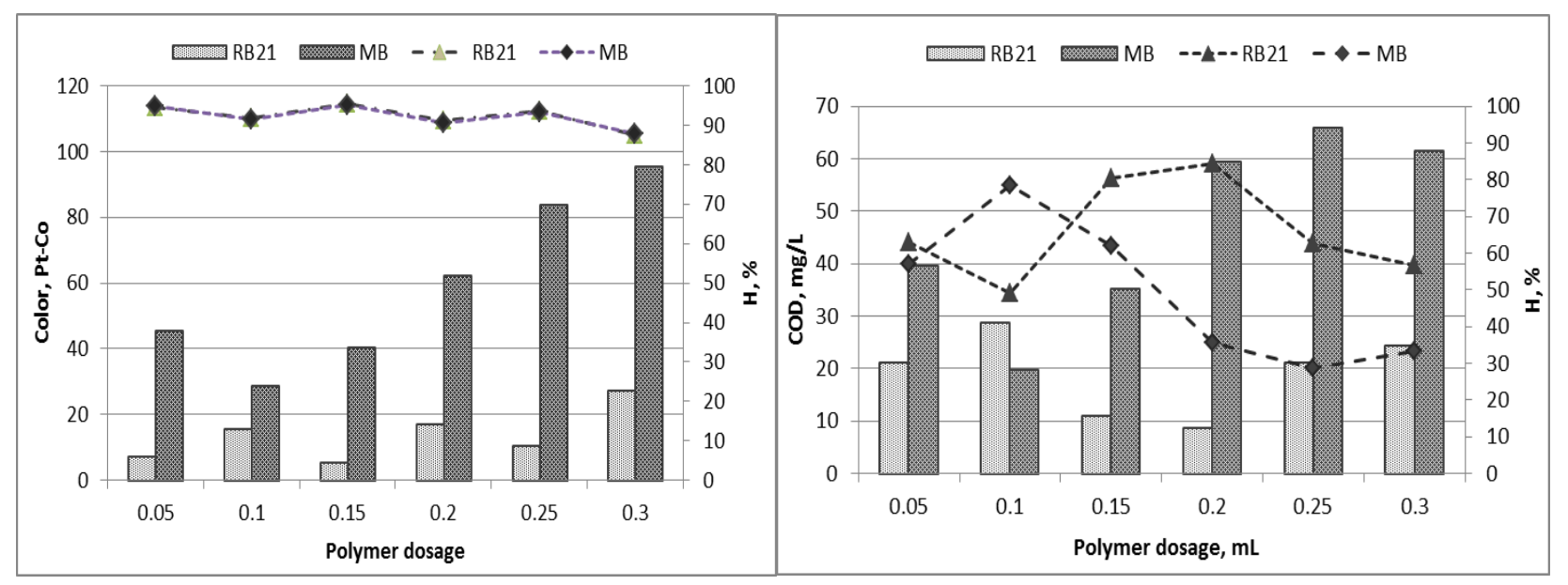

Figure 8. The impact on color and COD removal of polymer dosage.

However, the redundant of the polymer can contribute to COD consequences in the lowering of effectiveness. The polymer that cannot contact to another charged particle will be bent and automatic contact to another surface of itself. So that, the high density of polymer has made the surface' colloids became saturated, they do not have enough space for binding, In this case, the colloids will be re-stabilized indicating for lower effect.

\subsection{Effect of Cassia fistula seed gum}

Adding CFG at the concentration of $0.05 \%$ could removal color and COD significantly. The performance of CFG at various dose was represented in figure 9. Obtaining indicated that $\mathrm{CFG}$ assists the flocculation process with treatment nearly $98 \%$ color for RB2 1 and $90 \%$ color for $\mathrm{MB}$ at $0.15 \mathrm{~mL}$ and $0.1 \mathrm{~mL}$, respectively. In the treatment of COD, the yield was quite considerable, at about $85 \%$ for $\mathrm{RB} 21$ and $70 \%$ for $\mathrm{MB}$ at the concentration of $0.05 \%$ can removal color and COD significantly. The endosperm's CFG contain an amount of the galactomannan polysaccharides including the cis-hydroxyl group which can interact with colloidal particles.These findings demonstrated for the suitable of CFG as an auxiliary in color and COD removing in comparing with the chemical polymer. With the similar performance, biodegradable, less $\mathrm{pH}$ dependence, and the easy to manufacture $\mathrm{CFG}$

can become a promising reagent for green treatment of wastewater.

\subsection{The effect of CFG and cationic polymer in color removing of textile wastewater}

In order to apply achievements with synthetic wastewater to the real operation, it is important to conduct the experiments with actual textile wastewater obtaining from the actual company in Binh Duong province. Figure 10 shows the effect of $\mathrm{pH}$ on color removal and figure 11 indicates the influence of agents' dosage to color reducing of textile wastewater.

The optimized parameters for the coagulation of textile wastewater using PAC were $\mathrm{pH}=6$ and dose $=0.6 \mathrm{~mL}$ could removal $66 \%$ of color. By adding CFG to PAC, the efficient of treatment was increased about $70 \%$ even at the lower dosage of PAC and CFG $(0.5 \mathrm{~mL}$ for each reagent). This trend could be explained by the combination of CF gum and PAC providing for a strong chelation of PAC-gum-dye or gum-PAC - dye that attached dye particles to form heavier sludge's flocs and sequenced in the ease to settle (R. S. Blackburn, 2004). The yield of combining PAC and polymer was a little bit lower than PAC and CFG, for instant $68 \%$ color was decreased at the same condition.
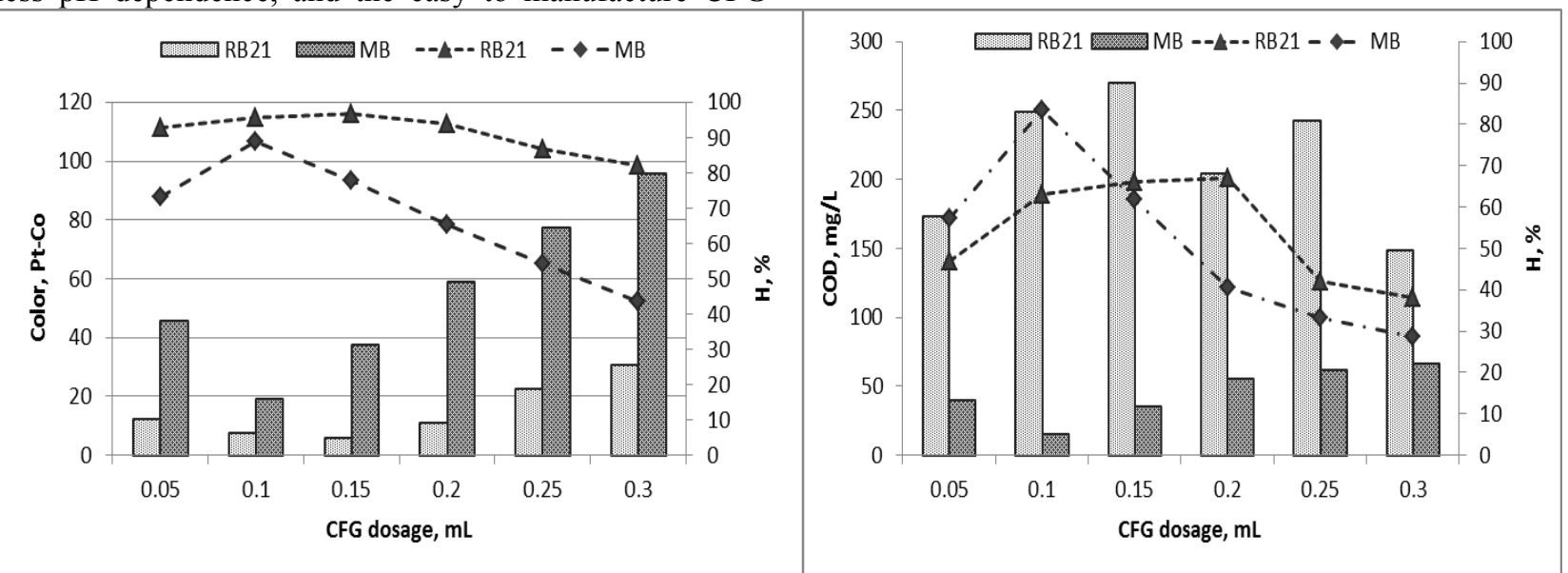

Figure 9. The impact on color and COD removal of CFG dosage 


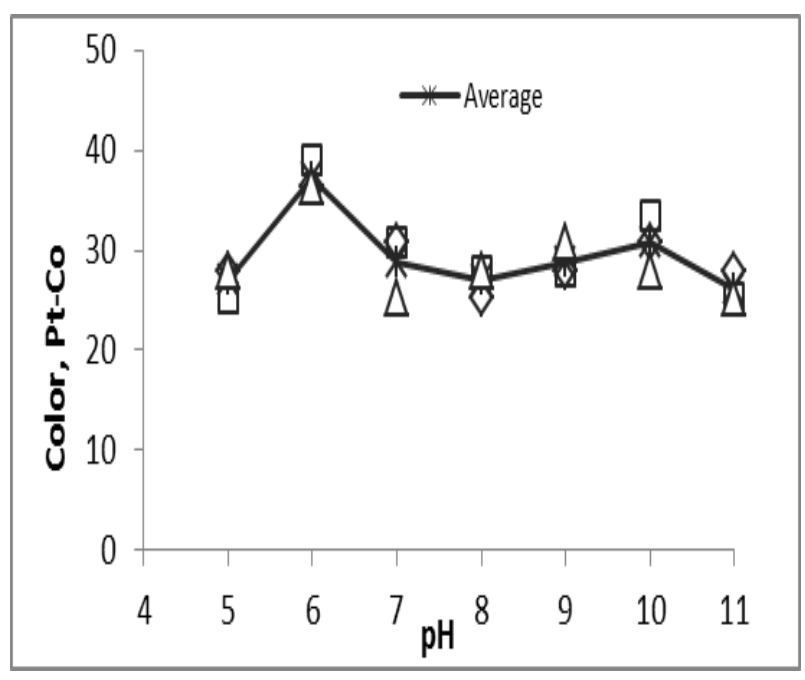

Figure 10. Effect of $\mathrm{pH}$ on color removal of textile wastewater.

\section{Conclusion}

Obtains from the batch mode treatments of synthetic wastewater containing RB21 and MB indicated that the optimal condition for color and COD removal by using PAC were: $\mathrm{pH}=4$ for $\mathrm{RB} 21$ and $\mathrm{pH}=6$ for $\mathrm{MB}$; the settling time was 30 minutes, the PAC dosage was 0.2 $\mathrm{mL}$. At optimal conditions of $\mathrm{pH}$ and PAC dose, the removing percentage of color was around $90 \%$ for RB2 1 and nearly $60 \%$ for $\mathrm{MB}$.

The supplement of the cationic polymer with PAC at 0.15 $\mathrm{mL}$ for RB21 and $0.1 \mathrm{~mL}$ for $\mathrm{MB}$ increased the color removal efficiency to $96 \%$ and $80 \%$, respectively. CFG assists the flocculation process at nearly $98 \%$ color for RB21 and $90 \%$ color for $\mathrm{MB}$ at $0.15 \mathrm{~mL}$ and $0.1 \mathrm{~mL}$, respectively. In the treatment of $\mathrm{COD}$, the yield was quite considerable, at about $85 \%$ for RB2 1 and $70 \%$ for MB at the concentration of $0.05 \%$ can removal color and COD significantly.

The optimized parameters for the coagulation of textile wastewater using PAC were $\mathrm{pH}=6$ and dosage $=0.6 \mathrm{~mL}$ can removal $66 \%$ of color. In addition of CFG to PAC, the efficient of treatment was increased about $70 \%$ even at the lower dosage of PAC and CFG $(0.5 \mathrm{~mL}$ for each reagent). The yield of combining $\mathrm{PAC}$ and polymer was a little bit lower than PAC and CFG, for instant $68 \%$ color was decreased at the same condition.

It could be concluded from above findings that $\mathrm{CFG}$ natural coagulant aid created a significant impact on the physical treatment of textile wastewater. Besides, with the ecofriendly characteristic and a low-cost method, CFG should be produced and applied in coagulationflocculation treatment various kind wastewater. We recommend conducting more experiments at the pilot scale in order to evaluate the feasibility of CFG as a coagulant with PAC for the treatment of continuous textile wastewater based on results of this research.

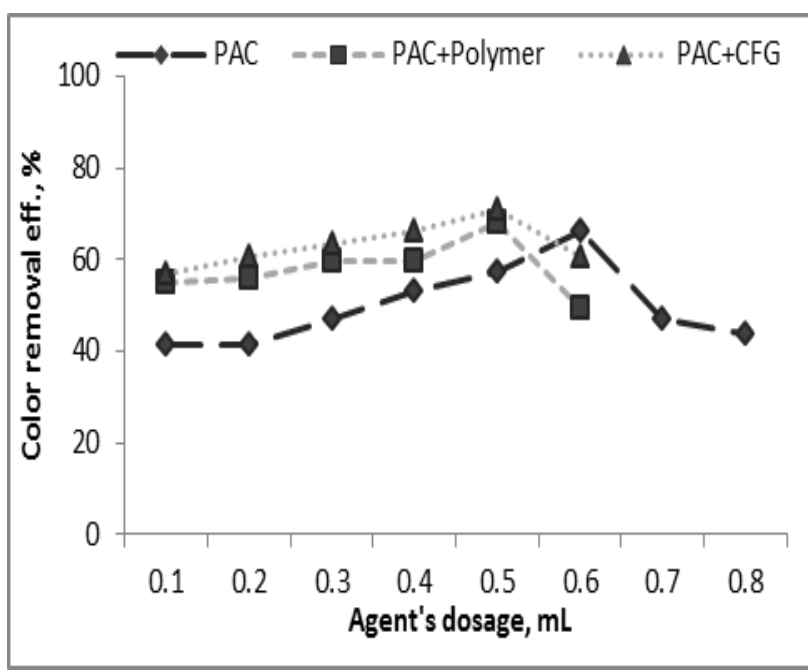

Figure 11. Effect of agent's dosage on color removal of textile wastewater.

\section{References}

[1] Akshaya Kumar Verma, Rajesh Roshan Dash, Puspendu Bhunia (2012). A review on chemical coagulation/flocculation technologies for removal of colour from textile wastewaters. Journal of Environmental Management 93: 154-168.

[2] A. Damayanti, Z. Ujang, M.R. Salim (2011). The influenced of PAC, zeolite, and Moringa oleifera as biofouling reducer (BFR) on hybrid membrane bioreactor of palm oil mill effluent (POME). Journal of Bioresource Technology 102: 4341-4346.

[3] APHA, AWWA and WBEF (1999). Standard methods for the examination of water and wastewater, $20^{\text {th }}$ Edition, Washington DC., USA.

[4] Bratby, J. (2007). Coagulation and Flocculation in Water and Wastewater Treatment, second edition, IWA Publishing.

[5] Chun-Yang Yin (2010). Emerging usage of plantbased coagulants for water and wastewater treatment. Process Biochemistry 45:1437-1444.

[6] Gao, B., Yue, Q., Miao, J. (2001). Evaluation of polyaluminium ferric chloride (PAFC) as a composite coagulant for water and wastewater treatment. Water Science and Technology 47 (1): 127-132.

[7] Gao, B.Y., Yue, Q.Y., Wang, Y., Zhou, W.Z. (2007). Color removal from dye-containing wastewater by magnesium chloride. Journal of Environmental Management 82: 167-172.

[8] Katrina Pui Yee Shak,Ta Yeong Wu (2015). Optimized use of alum together with un modified Cassia obtusifolia seed gum as a coagulant aid in treatment of palm oil mill effluent under natural $\mathrm{pH}$ of wastewater. Industrial Crops and Products 76: 1169-1178.

[9] Katrina Pui Yee Shak, Ta Yeong Wu (2014). Coagulation-flocculation treatment of high-strength agroindustrial wastewater using natural Cassia obtusifolia seed gum: Treatment efficiencies and flocs characterization. Chemical Engineering Journal 256: 
293-305.

[10] Le Hoang Viet and Nguyen Vo Chau Ngan (2014). Wastewater treatment technology. Can Tho university Publishing.

[11] Metcalf \& Eddy (2007). Water Reuse. Issues, Technologies, and Applications. McGraw-Hill Inc. ISBN13: 978-0-07-145927-3.

[12] M. A. Hanif, R. Nadeem, M. N. Zafar, H. N. Bhatti, R. Nawaz (2007). Kinetic studies for Ni(II) biosorption from industrial wastewater by Cassia fistula (Golden Shower) biomass. Journal of Hazardous Materials 145:501-505.

[13] Muhammad Asif Hanif, Raziya Nadeem, Muhammad Nadeem Zafar, Haq Nawza Bhatti and Rakshanda Nawaz (2007): 'Physico - Chemical Treatment of Textile Wastewater using Natural Coagulant Cassia fistula (Golden Shower) Pod Biomass'. Journal of Hazard. Mater 145:501-15.

[14] Perng, Yuan- Shing; Bui, Ha- Manh (2014). Decolorization of reactive dyeing wastewater by Poly A1uminium Chloride. Journal of Vietnam Environment,
5(1): 8-11.

[15] Peavy, H.S., Rowe, D.R., Tchobanoglous, G. (1985). Environmental Engineering. McGraw-Hill International Edition, New Delhi.

[16] Sook Yan Choy, Krishna Murthy Nagendra Prasad, Ta Yeong Wu, Mavinakere Eshwaraiah Raghunandan, Ramakrishnan Nagasundara Ramanan (2014). Utilization of plant-based natural coagulants as future alternatives towards sustainable water clarification. Journal of Environmental Sciences 26: 21782189.

[17] Yuan Shing Perng and Manh Ha Bui (2015). The feasibility of Cassia fistula gum with polyaluminum chloride for the decolorization of reactive dyeing wastewater. Journal of The Serbian Chemical Socirty 80 (1):115-125.

[18] Wennie Subramonian, TaYeongWu, Siang-PiaoChai (2014). A comprehensive study on coagulant performance and floc characterization of natural Cassia obtusifolia seed gum in treatment of raw pulp and paper mill effluent. Industrial Crops and Products 61:317-324. 